\title{
Response Agronomic Traits of Lentil Varieties to Zinc Fertilization in Calcareous and Terrace Soils of Bangladesh
}

\author{
Md. Ashraf Hossain ${ }^{1}$, Md. Abdul Quddus ${ }^{2, ~}{ }^{*}$, Md. Abdus Sattar ${ }^{1}$, Md. Babul Anwar ${ }^{3}$, \\ Shamima Aktar ${ }^{4}$, Mohammad Hossain Sarker ${ }^{1}$, Md. Razzab Ali ${ }^{5}$ \\ ${ }^{1}$ Farm Division, Bangladesh Agricultural Research Institute, Gazipur, Bangladesh \\ ${ }^{2}$ Soil and Water Management Section, Horticulture Research Centre, Bangladesh Agricultural Research Institute, Gazipur, Bangladesh \\ ${ }^{3}$ Regional Agricultural Research Station, Bangladesh Agricultural Research Institute, Jashore, Bangladesh \\ ${ }^{4}$ Pulses Research Sub-Station, Bangladesh Agricultural Research Institute, Gazipur, Bangladesh \\ ${ }^{5}$ Olericulture Division, Bangladesh Agricultural Research Institute, Gazipur, Bangladesh
}

\section{Email address:}

ashrafbdpro@gmail.com (Md. A. Hossain), quddus06@yahoo.com (Md. A. Quddus), sattar72@gmail.com (Md. A. Sattar), babul.bari08@yahoo.com (Md. B. Anwar), shamimapre@gmail.com (S. Aktar), hossain.agro@yahoo.com (M. H. Sarker), razzab321@gmail.com (Md. R. Ali)

${ }^{*}$ Corresponding author

\section{To cite this article:}

Md. Ashraf Hossain, Md. Abdul Quddus, Md. Abdus Sattar, Md. Babul Anwar, Shamima Aktar, Mohammad Hossain Sarker, Md. Razzab Ali. Response Agronomic Traits of Lentil Varieties to Zinc Fertilization in Calcareous and Terrace Soils of Bangladesh. Journal of Energy and Natural Resources. Special Issue: Assessment of Potassium Element on Lentil (Lens culinaris Medic) Agronomy and Nutrient Use Efficiency in Calcareous Soils. Vol. 8, No. 4, 2019, pp. 155-165. doi: 10.11648/j.jenr.20190804.14

Received: November 19, 2019; Accepted: November 29, 2019; Published: December 6, 2019

\begin{abstract}
Zinc (Zn) fertilization is reflected a significant agronomic strategy for global food security. Deficiency of zinc in soils could be caused to decrease the crop yield. Hence an experiment was made over two years at the research farm of Pulses Research Sub-Station of Bangladesh Agricultural Research Institute (BARI), Gazipur and in the research farm of Regional Agricultural Research Station (RARS), Ishwardi and Jessore, during Rabi season to assess the sensitivity of different varieties of lentil to $\mathrm{Zn}$ fertilization and evaluate the $\mathrm{Zn}$ in terms of yield and $\mathrm{Zn}$ mineral content in seed. There were 12 treatment combinations comprising six lentil varieties ( $\mathrm{V}_{1}=\mathrm{BARI}$ Masur-2, $\mathrm{V}_{2}=\mathrm{BARI}$ Masur-3, $\mathrm{V}_{3}=\mathrm{BARI}$ Masur-4, $\mathrm{V}_{4}=\mathrm{BARI}$ Masur-5, $\mathrm{V}_{5}=$ BARI Masur- 6 and $\mathrm{V}_{6}=$ BARI Masur-7) and two levels of zinc $\left(0\right.$ and $\left.2 \mathrm{~kg} \mathrm{ha}^{-1}\right)$. The experiment was laid out in split-plot design with three replications. Results reveal that growth, yield attributes and yield varied positively by zinc level and variety. Among the varieties, BARI Masur-7 followed by BARI Masur- 6 gave the highest seed yield. Interaction of variety and zinc the highest mean seed yield (1568 kg ha ${ }^{-1}$ at Gazipur, $2396 \mathrm{~kg} \mathrm{ha}^{-1}$ at Ishurdy and $1639 \mathrm{~kg} \mathrm{ha}^{-1}$ at Jashore) produced by the treatment $\mathrm{V}_{6} \mathrm{Zn}_{2}$. The improved protein content (28.5\% at Gazipur, $28.9 \%$ at Ishurdy and $29 \%$ at Jashore) and zinc content (70.2 ppm at Gazipur, $73.6 \mathrm{ppm}$ at Ishurdy and $69.9 \mathrm{ppm}$ at Jashore) was achieved in $\mathrm{V}_{6} \mathrm{Zn}_{2}$ treatment. The result, suggest that $2 \mathrm{~kg} \mathrm{Zn} \mathrm{ha}^{-1}$ could be applied in any lentil variety for quality improvement and yield maximization in terrace and calcareous soils of Bangladesh. The current study recommended conducting another experiment for further monitoring and determining the appropriate $\mathrm{Zn}$ dose for lentil production through application of different zinc rates in $\mathrm{Zn}$ - deficient soils.
\end{abstract}

Keywords: Lentil Varieties, Zinc, Yield, Quality, Calcareous and Terrace Soil

\section{Introduction}

Lentil (Lens culinaris) is an edible pulse which belongs to sub-family Faboideae under the family Fabaceae. It is one of the popular food legumes in Bangladesh and rank first in respect of consumer's preference and second in terms of area
(154000 ha) and production (116000 $\mathrm{mt})$ [1]. Lentil is considered a relatively affordable, high protein, fibers, antioxidants and micronutrients including iron, zinc, selenium and vitamin ( $\mathrm{A}$ and $\mathrm{B}$ complex), folate and $\beta$ carotene $[2,3]$. Furthermore, lentil enhances of soil fertility by biologically nitrogen fixation (BNF) and can fix 8-14 kg 
$\mathrm{N} \mathrm{ha}^{-1}$ [4]. The agronomic significance of lentil is related to high protein content and micronutrients like $\mathrm{Zn}$. Insufficiency of $\mathrm{Zn}$ nutrient has been documented in terrace and calcareous soils of Bangladesh [5]. This element is less available for plant uptake in high $\mathrm{pH}$ soils (e.g. calcareous soils) mainly due to their retention by soils and soil constituents [6]. The terrace soil is acidic in reaction with low organic matter and mainly phosphate fixing, and low in $\mathrm{P}, \mathrm{K}, \mathrm{S}, \mathrm{Zn}$ and $\mathrm{B}$ levels $[7,8]$. Zinc deficiency has occurred mainly due to continuous mining of this nutrient from soil and to increase cropping intensity [9]. Zinc deficiency is the most widespread micronutrient deficiency in the world [10].

However, the present dietary value and reflecting an increasing beneficial effect of lentil in human body and soil fertility, the effort should be taken to increase productivity through using high yielding variety of lentil and appropriate nutrient management. Several works have been done globally regarding the rate determination of micronutrient fertilizer in micronutrient deficient condition [11-13]. Sommer and Lipman [14] were the first to prove the essentiality of $\mathrm{Zn}$ as a nutrient requirement for higher plants. Plants emerged from seeds with low concentration of $\mathrm{Zn}$ could be highly sensitive to biotic and abiotic stress [15]. Zinc requirement of pulses might be higher than cereals. In the country like Bangladesh, the farmers have been taken less attention on proper nutrient management practices for legume cultivation especially micronutrient like $\mathrm{Zn}$. Keeping the above points of view, the present study was undertaken to assess the sensitivity of different varieties of lentil to $\mathrm{Zn}$ fertilization and to evaluate the $\mathrm{Zn}$ in terms of yield and $\mathrm{Zn}$ mineral content in seed.

\section{Materials and Methods}

Field experiments were conducted in three locations for two consecutive years (winter season of 2012-13 and 2013-
14). Three locations were viz. (i) at the research farm of Pulses Research Sub-Station, Bangladesh Agricultural Research Institute (BARI), Gazipur, (ii) at the research field of Regional Agricultural Research Station, BARI, Ishurdy and (iii) at the research field of Regional Agricultural Research Station, BARI, Jashore, Bangladesh. The terrace soils of Gazipur farm was medium high land with finetextured (clay loam) belongs to Chhiata series under the agro ecological zone - Madhupur Tract (AEZ-28). The experimental field of Ishurdy was medium high land, calcareous in nature and the soil was clay loam in texture. The land of Jashore belongs to Gopalpur soil series and calcareous in nature having silt loam texture. The soils of both Ishurdy and Jashore are under High Ganges River Floodplain agroecological zone-11. The all experimental sites have subtropical humid climatic conditions which are characterized by relatively high monsoon rainfall, high humidity, and high temperature. Long day with less clear sunshine, sometimes the sky remains cloudy for heavy rainfall during April to September. The scanty rainfall, low humidity and low temperature, short day and more clear sunshine during October to March. During experimental period in Gazipur, two years average total rainfall was received from $130 \mathrm{~mm}$. The mean minimum air temperatures of 10 to $12^{\circ} \mathrm{C}$ and maximum air temperatures 25 to $33.5^{\circ} \mathrm{C}$ during growing period. In Ishurdy, two years average total rainfall got $70.5 \mathrm{~mm}$ during growing period. The average minimum temperatures of 7 to $11^{\circ} \mathrm{C}$ and average maximum temperatures were of 22 to $33^{\circ} \mathrm{C}$ in experimental period. The Jashore area got average total rainfall $88.8 \mathrm{~mm}$, average minimum temperatures of 8.9 to $13.5^{\circ} \mathrm{C}$ and average maximum temperatures were of 20 to $33.8^{\circ} \mathrm{C}$ in experimental period. Before starting the experiment initial soil $(0-15 \mathrm{~cm})$ samples of three locations have been analyzed and chemical properties are presented in the Table 1.

Table 1. Fertility status of initial soils of experimental field at Gazipur, Ishurdy and Jashore.

\begin{tabular}{|c|c|c|c|c|c|c|c|c|c|}
\hline \multirow{2}{*}{ Location } & \multirow{2}{*}{ pH } & \multirow{2}{*}{ OM (\%) } & \multirow{2}{*}{ Total N (\%) } & $\mathbf{C a}$ & $\mathbf{K}$ & $\mathbf{P}$ & $\mathbf{S}$ & Zn & B \\
\hline & & & & \multicolumn{2}{|c|}{ meq. $100 \mathrm{~g}^{-1}$} & \multicolumn{2}{|l|}{$\mu \mathrm{g} \mathrm{g}^{-1}$} & & \\
\hline Gazipur (result) & 6.1 & 1.30 & 0.063 & 7.2 & 0.11 & 12 & 14.2 & 0.86 & 0.16 \\
\hline Critical level & - & - & 0.12 & 2.0 & 0.12 & 7 & 10 & 0.60 & 0.20 \\
\hline Interpretation* & acidic & low & very low & high & low & medium & medium & low & low \\
\hline Ishurdy (result) & 7.6 & 1.42 & 0.069 & 13.2 & 0.17 & 14 & 15 & 0.90 & 0.19 \\
\hline Jashore (result) & 8.1 & 1.44 & 0.078 & 20.0 & 0.18 & 13 & 14.5 & 0.89 & 0.18 \\
\hline Critical level & - & - & 0.12 & 2.0 & 0.12 & 10 & 10 & 0.60 & 0.20 \\
\hline
\end{tabular}

$(*$ FRG, 2012)

There were 12 treatment combinations containing six lentil varieties $\left(\mathrm{V}_{1}=\right.$ BARI Masur-2, $\mathrm{V}_{2}=$ BARI Masur-3, $\mathrm{V}_{3}=$ BARI Masur-4, $\mathrm{V}_{4}=$ BARI Masur-5, $\mathrm{V}_{5}=$ BARI Masur- 6 and $\mathrm{V}_{6}=$ BARI Masur-7) and two levels of zinc ( 0 and $\left.2 \mathrm{~kg} \mathrm{ha}^{-1}\right)$. The 12 treatment combinations were as $\mathrm{V}_{1} \mathrm{Zn}_{0} ; \mathrm{V}_{1} \mathrm{Zn}_{2} ; \mathrm{V}_{2} \mathrm{Zn}_{0}$; $\mathrm{V}_{2} \mathrm{Zn}_{2} ; \mathrm{V}_{3} \mathrm{Zn}_{0} ; \mathrm{V}_{3} \mathrm{Zn}_{2} ; \mathrm{V}_{4} \mathrm{Zn}_{0} ; \mathrm{V}_{4} \mathrm{Zn}_{2} ; \mathrm{V}_{5} \mathrm{Zn}_{0} ; \mathrm{V}_{5} \mathrm{Zn}_{2} ; \mathrm{V}_{6} \mathrm{Zn}_{0}$; and $\mathrm{V}_{6} \mathrm{Zn}_{2}$ following main plot and sub-plot system. The experiment was laid out in split-plot design with three replications. The main plot was considered as variety factor and sub-plot was as $\mathrm{Zn}$ factor. The unit sub-plot size was $4 \mathrm{~m}$ $\times 3 \mathrm{~m}$. The blanket fertilizers dose of N, P, K, S and B @ 20, 20, 40, 10 and $1 \mathrm{~kg} \mathrm{ha}^{-1}$, respectively used in all treatment plots as urea, TSP, MoP, gypsum and boric acid at the time of final plot preparation. Zinc was applied treatments basis as $\mathrm{ZnSO}_{4}$ $(36 \% \mathrm{Zn})$. Seeds of lentil varieties were treated using the fungicide Provex 200 (at $2.5 \mathrm{~g} \mathrm{~kg}^{-1}$ seeds) before sowing to control of root rot disease. Treated seeds of all varieties were sown@35 kg ha ${ }^{-1}$ with a spacing of $30 \mathrm{~cm} \times$ continuous on 4 November, 2012 \& 23 November, 2013 at Gazipur, on 15 November, 2012 \& 10 November, 2013 at Ishurdy and on 1 
November, 2012 \& 24 November, 2013 at Jashore. Manually weeding as well as thining of seedlings was done at 25 days after sowing (DAS). Again hand weeding was done at 50 days after sowing. The disease of stemphylium blight was control by three times spraying of Rovral fungicide @ $2 \mathrm{~g} \mathrm{~L}^{-1}$ of water at interval of 10 days, first start at flowering stage and two times insecticide (Karate @ $2 \mathrm{ml} \mathrm{L}^{-1}$ of water) sprayed at 10 days interval starting from 60 DAS to overcome insect infestation. Crop was harvested at maturity.

Data on seed yield $\left(\mathrm{kg} \mathrm{ha}^{-1}\right)$ at around $10 \%$ moisture basis were recorded from the whole plot technique.

The growth and yield attributes namely: plant height, number of branch per plant and number of pods per plant were recorded from ten plants selected randomly from each unit plot. Pods were detached from every plant and the number of pods per plant was counted and averaged. Hundred seed weight $(\mathrm{g})$ was determined by the counting of 100 seeds randomly from each plot and weighing through electronic balance. The data of nodule per plant was recorded at 55 days after sowing in each plot by selecting of 5 plants randomly. The plants of lentil were smoothly uprooted and carefully removed the soil from roots by water. Then washed the roots with water, blotted with tissue paper and counted the number of nodules. Percentage of harvest index (HI) was determined by the formula-

$$
H I=\frac{\text { Economic yield }}{\text { Biological yield }} \times 100
$$

Initial soil sample (0-15 cm depth) of three locations were collected and brought to the laboratory and spread on a brown paper for air drying. The air-dried soil samples were ground and passed through a $2-\mathrm{mm}$ sieve. The sieving soil samples were kept into plastic container with proper label for chemical analysis.

Soil $\mathrm{pH}$ was measured by glass electrode $\mathrm{pH}$ meter using soil: water ratio of $1: 2.5$ [16]. Organic carbon was determined following the wet oxidation method as described by Page et al. [16] and the organic matter content was calculated by multiplying the \% organic carbon with the Van Bemmelen factor 1.73. Total $\mathrm{N}$ by Microkjeldahl method [17]; available $\mathrm{P}$ was determined following Olsen method for calcareous soil as described by Page et al. [16] and Bray and Kurtz [18] method for terrace soil; exchangeable $\mathrm{K}$ by $1 \mathrm{~N}$ $\mathrm{NH}_{4} \mathrm{OAc}$ method [19]; exchangeable $\mathrm{Ca}$ by $1 \mathrm{~N} \mathrm{NH}_{4} \mathrm{OAc}$ method [20]; available $\mathrm{S}$ by turbidity method using $\mathrm{BaCl}_{2}$ [21]; available $\mathrm{Zn}$ by DTPA method [22]; available B by azomethine-H method [16].

Ground seed samples were digested with di-acid mixture
$\left(\mathrm{HNO}_{3}-\mathrm{HClO}_{4}\right)$ (5: 1) as described by Piper [23] for the determination- concentration of $\mathrm{N}$ (Micro-Kjeldahl method) and $\mathrm{Zn}$ (atomic absorption spectrophotometer method, VARIAN SpectrAA 55B, Australia). Protein content was measured by estimating the $\mathrm{N}$ concentration and then multiplying the $\mathrm{N}$ value by 6.25 [24].

Data of growth and yield attributes, nodules per plant, $\mathrm{N}$ and protein content were statistical analyzed through ANOVA procedure using a split-plot design with three replications considering main-plot factor variety and sub-plot factor $\mathrm{Zn}$. Then multiple comparisons like all-pairwise comparisons i.e. the means of treatment tested by LSD method at 5\% (LSD 0.05) level of significance [25].

\section{Result}

\subsection{Varietal Performance}

In case of lentil variety, the growth and yield parameters exhibited significant variation among themselves (Table 2). In Gazipur, the plant height of lentil varied across the varieties from 27.5 to $32.8 \mathrm{~cm}$. The highest plant height $(32.8 \mathrm{~cm})$ was recorded from the variety $\mathrm{V}_{6}$ (BARI Masur-7) which was significantly different over the other variety but statistically identical with $V_{5}$ and $V_{2}$ variety. The lowest plant height (27.5 $\mathrm{cm}$ ) was found in $\mathrm{V}_{4}$ variety. In Ishurdi, the plant height was ranged from 31.8 to $37.2 \mathrm{~cm}$ across the varieties where, the significantly highest plant height was obtained from $\mathrm{V}_{6}$ variety followed by $\mathrm{V}_{5}, \mathrm{~V}_{2}$ and $\mathrm{V}_{1}$ variety. In case of plant height in Jashore, varied among the variety from 32.3 to $37.7 \mathrm{~cm}$. The tall plant also documented in $\mathrm{V}_{6}$ which was statistically similar to $\mathrm{V}_{5}, \mathrm{~V}_{2}$ and $\mathrm{V}_{1}$ variety and dwarf plant was found in $\mathrm{V}_{4}$ variety (Table 2). Number of branches per plant varied among the lentil varieties from 3.91 to 5.44 at Gazipur, 4.54 to 6.04 at Ishurdi and 5.06 to 6.44 at Jashore. The maximum number of branches per plant (5.44) was recorded in $\mathrm{V}_{5}$ variety at Gazipur which was significantly different over the others varieties but statistically alike with $\mathrm{V}_{6}$ variety. Significantly highest number of branches per plant was achieved in the variety $V_{6}$ in both the location of Ishurdi and Jashore and lowest was in $V_{1}$ variety (Table 2). The maximum number of pods per plant was produced (65.3 at Gazipur, 82.4 at Ishurdi and 101 at Jashore) by $\mathrm{V}_{6}$ (BARI Masur-7) which was showed significantly variation among the others varieties at Gazipur but statistically similar to $\mathrm{V}_{2}$ at Ishurdy and similar to $\mathrm{V}_{5}, \mathrm{~V}_{2} \& \mathrm{~V}_{1}$ at Jashore. The minimum number of pods per plant was noted from $V_{3}$ variety at Gazipur and Jashore while it was found minimum in $\mathrm{V}_{1}$ variety at Ishurdy (Table 2).

Table 2. Main effects of lentil varieties on growth and yield attribute (Pooled data of two years).

\begin{tabular}{|c|c|c|c|c|c|c|c|c|c|}
\hline \multirow{2}{*}{ Varieties } & \multicolumn{3}{|c|}{ Plant height (cm) } & \multicolumn{3}{|c|}{ No. of branches plant ${ }^{-1}$} & \multicolumn{3}{|c|}{ No. of pods plant ${ }^{-1}$} \\
\hline & Gazipur & Ishurdy & Jashore & Gazipur & Ishurdy & Jashore & Gazipur & Ishurdy & Jashore \\
\hline $\mathrm{V}_{1}$ & $29.0 \mathrm{bc}$ & $34.4 \mathrm{ab}$ & $35.3 \mathrm{abc}$ & $3.92 \mathrm{~b}$ & $4.54 \mathrm{~b}$ & $5.06 \mathrm{~b}$ & $56.1 \mathrm{bc}$ & $74.5 \mathrm{c}$ & $93.6 \mathrm{ab}$ \\
\hline $\mathrm{V}_{2}$ & $30.5 \mathrm{ab}$ & $34.9 \mathrm{ab}$ & $35.4 \mathrm{ab}$ & $3.91 b$ & $4.59 \mathrm{~b}$ & $5.39 \mathrm{~b}$ & $58.8 \mathrm{~b}$ & $79.5 \mathrm{ab}$ & $95.5 \mathrm{ab}$ \\
\hline $\mathrm{V}_{3}$ & $27.8 \mathrm{c}$ & $32.4 b$ & $33.0 \mathrm{bc}$ & $4.33 b$ & $5.05 \mathrm{ab}$ & $5.71 \mathrm{ab}$ & $52.7 \mathrm{c}$ & $76.4 \mathrm{bc}$ & $82.5 c$ \\
\hline $\mathrm{V}_{4}$ & $27.5 \mathrm{c}$ & $31.8 \mathrm{~b}$ & $32.3 \mathrm{c}$ & $4.37 b$ & $4.87 b$ & $5.66 \mathrm{ab}$ & $59.0 \mathrm{~b}$ & $77.7 \mathrm{bc}$ & $92.4 \mathrm{~b}$ \\
\hline $\mathrm{V}_{5}$ & $30.7 \mathrm{ab}$ & $36.1 \mathrm{a}$ & $36.8 \mathrm{a}$ & $5.44 \mathrm{a}$ & $5.93 \mathrm{a}$ & $6.30 \mathrm{a}$ & $58.1 \mathrm{~b}$ & $77.1 \mathrm{bc}$ & $99.0 \mathrm{ab}$ \\
\hline $\mathrm{V}_{6}$ & $32.8 \mathrm{a}$ & $37.2 \mathrm{a}$ & $37.7 \mathrm{a}$ & $5.34 \mathrm{a}$ & $6.04 \mathrm{a}$ & $6.44 a$ & $65.3 \mathrm{a}$ & $82.4 a$ & $101 \mathrm{a}$ \\
\hline CV (\%) & 6.52 & 7.42 & 6.70 & 11.7 & 15.7 & 11.3 & 5.41 & 4.66 & 7.0 \\
\hline
\end{tabular}




\begin{tabular}{llllllllll}
\hline \multirow{2}{*}{ Varieties } & \multicolumn{2}{l}{ Plant height $(\mathbf{c m})$} & \multicolumn{2}{l}{ No. of branches plant } \\
\cline { 2 - 9 } & Gazipur & Ishurdy & Jashore & Gazipur & Ishurdy & Jashore & Gazipur & Ishurdy & Jashore \\
\hline LSD $(0.05)$ & 2.49 & 3.29 & 3.02 & 0.69 & 1.05 & 0.84 & 4.05 & 4.67 \\
\hline
\end{tabular}

In a column, the values having common letter do not differ significantly $(\mathrm{P} \leq 0.05)$

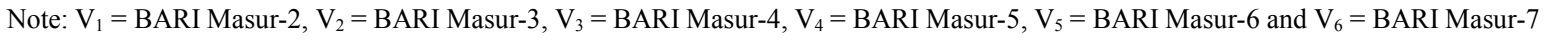

In case of seed weight, the heaviest seed (2.29 $\mathrm{g}$ at Gazipur and $2.28 \mathrm{~g}$ at Ishurdi) was obtained from $\mathrm{V}_{2}$ variety which was significantly different with the others variety at Gazipur but it was showed non-significant at Ishurdi. In Jashore, the highest seed weight $(2.41 \mathrm{~g})$ was recorded from $\mathrm{V}_{6}$ variety that was showed significant variation among the other varieties. The lowest seed weight was noted in V1 variety in all the locations. Nodulation showed significantly variation among the different lentil varieties in all the locations (Table 3). The highest number of nodules per plant (36.7) at Gazipur was noted in the variety $V_{3}$ that was statistically alike to $V_{6}$, $\mathrm{V}_{5}$ and $\mathrm{V}_{4}$ variety. The lowest nodulation (27.6) was found in $\mathrm{V}_{2}$ variety. In the locations of Ishurdi and Jashore, the maximum number of nodules per plant (35.9 at Ishurdi and 38.0 at Jashore) was counted in the variety $\mathrm{V}_{6}$ which was statistically similar with $\mathrm{V}_{5}, \mathrm{~V}_{4}$ and $\mathrm{V}_{3}$ at Ishurdi and $\mathrm{V}_{5}, \mathrm{~V}_{4}$, $\mathrm{V}_{3}$ and $\mathrm{V}_{2}$ at Jashore. The lowest nodulation was observed in $\mathrm{V}_{2}$ (27.6) at Ishurdi and $\mathrm{V}_{1}$ (29.6) at Jashore which was statistically inferior with the other varieties (Table 3 ).

Table 3. Main effects of lentil varieties on yield attribute (Pooled data of two years).

\begin{tabular}{|c|c|c|c|c|c|c|}
\hline \multirow{2}{*}{ Varieties } & \multicolumn{3}{|c|}{100 seed wt. (g) } & \multicolumn{3}{|c|}{ No. of nodules plant ${ }^{-1}$} \\
\hline & Gazipur & Ishurdy & Jashore & Gazipur & Ishurdy & Jashore \\
\hline $\mathrm{V}_{1}$ & $1.78 \mathrm{c}$ & 2.13 & $1.84 \mathrm{e}$ & $29.1 \mathrm{bc}$ & $27.8 \mathrm{~b}$ & $29.6 b$ \\
\hline $\mathrm{V}_{2}$ & $2.29 \mathrm{a}$ & 2.28 & $2.26 \mathrm{c}$ & $27.6 \mathrm{c}$ & $27.6 b$ & $35.0 \mathrm{ab}$ \\
\hline $\mathrm{V}_{3}$ & $2.06 \mathrm{~b}$ & 2.27 & $2.31 \mathrm{~b}$ & $36.7 \mathrm{a}$ & $34.7 \mathrm{a}$ & $35.3 \mathrm{ab}$ \\
\hline $\mathrm{V}_{4}$ & $2.00 \mathrm{~b}$ & 2.20 & $2.23 \mathrm{~d}$ & $32.5 \mathrm{abc}$ & $34.5 \mathrm{a}$ & $34.3 \mathrm{ab}$ \\
\hline $\mathrm{V}_{5}$ & $1.98 \mathrm{~b}$ & 2.19 & $2.21 \mathrm{~d}$ & $33.8 \mathrm{ab}$ & $31.8 \mathrm{ab}$ & $33.2 \mathrm{ab}$ \\
\hline $\mathrm{V}_{6}$ & $2.02 \mathrm{~b}$ & 2.17 & $2.41 \mathrm{a}$ & $34.5 \mathrm{ab}$ & $35.9 \mathrm{a}$ & $38.0 \mathrm{a}$ \\
\hline $\operatorname{LSD}(0.05)$ & 0.13 & $\mathrm{~ns}$ & 0.023 & 5.98 & 6.13 & 7.13 \\
\hline
\end{tabular}

In a column, the values having common letter do not differ significantly $(\mathrm{P} \leq 0.05)$

Note: $\mathrm{V}_{1}=$ BARI Masur-2, $\mathrm{V}_{2}=$ BARI Masur-3, $\mathrm{V}_{3}=$ BARI Masur- $4, \mathrm{~V}_{4}=$ BARI Masur-5, $\mathrm{V}_{5}=$ BARI Masur- 6 , and V $\mathrm{V}_{6}=$ BARI Masur-7

In case of seed yield of lentil, significantly the highest yield (1471 kg ha ${ }^{-1}$ in $1^{\text {st }}$ year and $1302 \mathrm{~kg} \mathrm{ha}^{-1}$ ) was produced by $\mathrm{V}_{6}=$ BARI Masur 7 at Gazipur but it was statistically identical by $\mathrm{V}_{5}, \mathrm{~V}_{4}, \mathrm{~V}_{3}$ and $\mathrm{V}_{2}$ variety in $1^{\text {st }}$ year. The lowest seed yield was produced by $\mathrm{V}_{1}=$ BARI Masur- 2 in both the years. In Ishurdy, the greatest seed yield $(2030 \mathrm{~kg}$ $\mathrm{ha}^{-1}$ ) was achieved in $\mathrm{V}_{5}=$ BARI Masur- 6 in $1^{\text {st }}$ year showed non-significant with other varieties but in $2^{\text {nd }}$ year it was obtained highest (2314 $\mathrm{kg} \mathrm{ha}^{-1}$ ) from $\mathrm{V}_{6}=$ BARI Masur-7 followed by $\mathrm{V}_{5}, \mathrm{~V}_{4}, \mathrm{~V}_{3}$ and $\mathrm{V}_{2}$ variety. The lowest seed yield produced by BARI Masur-2 in both the years. In Jashore, the highest seed yield (1599 $\mathrm{kg} \mathrm{ha}^{-1}$ ) got from $\mathrm{V}_{6}=$ BARI Masur7 in $1^{\text {st }}$ year which statistically resemble with most of the varieties although highest yield (1599 $\left.\mathrm{kg} \mathrm{ha}^{-1}\right)$ acquired by $\mathrm{V}_{5}$ $=$ BARI Masur- 6 in $2^{\text {nd }}$ year which was significantly different over other varieties but statistically at par $\mathrm{V}_{6}$ and $\mathrm{V}_{2}$ variety (Table 4). In the experiment, harvest index (HI) of lentil was ranged across the varieties from 41.2 to $44.4 \%$ at Gazipur, 45.6 to $46.5 \%$ at Ishurdy and 42.8 to $45.6 \%$ at Jashore, respectively, where the significantly highest $\mathrm{HI}$ (44.4\%) was recorded from $V_{6}$ variety and lowest $H I$ was found in $V_{1}$ variety for Gazipur. The highest harvest index was recorded at Ishurdy from $\mathrm{V}_{2}$ variety which showed non-significant. The highest HI was found in V1 variety for Jashore that was statistically similar with most of the varieties (Table 4).

Table 4. Main effects of lentil varieties on yield and harvest index.

\begin{tabular}{|c|c|c|c|c|c|c|c|c|c|}
\hline \multirow{3}{*}{ Varieties } & \multicolumn{6}{|c|}{ Seed yield $\left(\mathrm{kg} \mathrm{ha}^{-1}\right)$} & \multicolumn{3}{|l|}{ HI (\%) } \\
\hline & \multicolumn{2}{|c|}{ Gazipur } & \multicolumn{2}{|l|}{ Ishurdy } & \multicolumn{2}{|c|}{ Jashore } & \multirow{2}{*}{ Gazipur } & \multirow{2}{*}{ Ishurdy } & \multirow{2}{*}{ Jashore } \\
\hline & $1^{\text {st }}$ Yr. & $2^{\text {nd }} \mathrm{Yr}$. & $\mathbf{1}^{\text {st }}$ Yr. & $2^{\text {nd }} \mathrm{Yr}$. & $1^{\text {st }}$ Yr. & $2^{\text {nd }} \mathrm{Yr}$. & & & \\
\hline $\mathrm{V}_{1}$ & $1219 b$ & $923 b$ & 1930 & $1867 \mathrm{~b}$ & $1543 a$ & $1391 b c$ & $41.2 \mathrm{c}$ & 45.6 & $45.6 \mathrm{a}$ \\
\hline $\mathrm{V}_{2}$ & $1262 \mathrm{ab}$ & $999 b$ & 2054 & $2209 a$ & $1482 \mathrm{a}$ & $1608 \mathrm{ab}$ & $41.6 \mathrm{c}$ & 46.5 & $45.1 \mathrm{a}$ \\
\hline $\mathrm{V}_{3}$ & $1323 \mathrm{ab}$ & $1062 b$ & 1995 & $2199 a$ & $1415 \mathrm{a}$ & $1520 \mathrm{~b}$ & $42.0 \mathrm{bc}$ & 46.3 & $44.9 \mathrm{a}$ \\
\hline $\mathrm{V}_{4}$ & $1286 \mathrm{ab}$ & $1011 \mathrm{~b}$ & 1980 & $2272 a$ & $1171 b$ & $1267 \mathrm{c}$ & $42.2 \mathrm{bc}$ & 46.4 & $42.8 b$ \\
\hline $\mathrm{V}_{5}$ & $1333 \mathrm{ab}$ & $1104 b$ & 2030 & $2214 a$ & $1578 \mathrm{a}$ & $1755 \mathrm{a}$ & $43.0 \mathrm{~b}$ & 45.9 & $45.5 \mathrm{a}$ \\
\hline CV (\%) & 14.5 & 14.2 & 10.4 & 9.66 & 9.86 & 11.5 & 1.87 & 5.85 & 3.41 \\
\hline $\operatorname{LSD}(0.05)$ & 249 & 195 & $\mathrm{~ns}$ & 270 & 186 & 227 & 1.02 & ns & 1.96 \\
\hline
\end{tabular}

In a column, the values having common letter do not differ significantly $(\mathrm{P} \leq 0.05)$

Note: $\mathrm{V}_{1}=$ BARI Masur-2, $\mathrm{V}_{2}=$ BARI Masur-3, $\mathrm{V}_{3}=$ BARI Masur-4, $\mathrm{V}_{4}=$ BARI Masur-5, $\mathrm{V}_{5}=$ BARI Masur-6, and V6 $=$ BARI Masur-7 
In the experiment, the highest protein content $(27.9 \%$ in Gazipur, $28.3 \%$ in Ishurdy and $28.2 \%$ in Jashore) was estimated in the seed lentil variety $\mathrm{V}_{6}=$ BARI Masur-7 which was significantly variation among the other varieties at Gazipur but at Ishurdy and Jashore it was showed nonsignificant (Table 5). In case of zinc content in seed, the zinc content varied across the varieties from 54.7 to $67.4 \mathrm{ppm}$ at Gazipur, 57.0 to $71.1 \mathrm{ppm}$ at Ishurdy and 54.2 to $67.8 \mathrm{ppm}$ at Jashore, where the highest zinc content was recorded from the variety $\mathrm{V}_{6}=$ BARI Masur-7 that was significantly different with the other varieties but statistically identical at par $\mathrm{V}_{5}=$ BARI Masur-6 in all the locations (Table 5).

Table 5. Main effects of lentil varieties on protein and zinc content (Pooled data of two years.

\begin{tabular}{|c|c|c|c|c|c|c|}
\hline \multirow{2}{*}{ Varieties } & \multicolumn{3}{|c|}{ Protein content $(\%)$} & \multicolumn{3}{|c|}{ Zinc content (ppm) } \\
\hline & Gazipur & Ishurdy & Jashore & Gazipur & Ishurdy & Jashore \\
\hline $\mathrm{V}_{1}$ & $26.7 \mathrm{~b}$ & 27.1 & 26.9 & $58.6 \mathrm{bc}$ & $60.0 \mathrm{~b}$ & $60.0 \mathrm{~b}$ \\
\hline $\mathrm{V}_{2}$ & $26.9 b$ & 27.2 & 27.3 & $59.9 b c$ & $57.0 \mathrm{~b}$ & $58.1 \mathrm{bc}$ \\
\hline $\mathrm{V}_{4}$ & $27.2 b$ & 27.3 & 26.8 & $61.5 \mathrm{abc}$ & $61.2 \mathrm{~b}$ & $57.1 \mathrm{bc}$ \\
\hline $\mathrm{V}_{5}$ & $26.8 b$ & 27.2 & 27.0 & $64.8 \mathrm{ab}$ & $68.3 \mathrm{a}$ & $65.9 \mathrm{a}$ \\
\hline $\mathrm{V}_{6}$ & $27.9 \mathrm{a}$ & 28.3 & 28.2 & $67.4 \mathrm{a}$ & $71.1 \mathrm{a}$ & $67.8 \mathrm{a}$ \\
\hline $\operatorname{LSD}(0.05)$ & 0.63 & $\mathrm{~ns}$ & $\mathrm{~ns}$ & 7.0 & 5.58 & 5.16 \\
\hline
\end{tabular}

In a column, the values having common letter do not differ significantly $(\mathrm{P} \leq 0.05)$

Note: $\mathrm{V}_{1}=$ BARI Masur-2, $\mathrm{V}_{2}=$ BARI Masur-3, $\mathrm{V}_{3}=$ BARI Masur-4, $\mathrm{V}_{4}=$ BARI Masur-5, $\mathrm{V}_{5}=$ BARI Masur-6, and V6 $=$ BARI Masur-7

\subsection{Effect of Zinc}

In case of lentil varieties, application of zinc showed positive variation among the different yield parameters (Tables $6 \& 7)$. The tallest plant of lentil ( $31.3 \mathrm{~cm}$ at Gazipur, $36.2 \mathrm{~cm}$ at Ishurdi and $36.7 \mathrm{~cm}$ at Jashore) was significantly found in the plot application of $2 \mathrm{~kg} \mathrm{Zn} \mathrm{ha}^{-1}$. The dwarf plant was observed in $\mathrm{Zn}$ control plot at all the locations (Table 6). The highest number of branches per plant (4.82 at Gazipur, 5.41 at Ishurdi and 6.06 at Jashore) and the maximum number of pods per plant (62.8 at Gazipur, 80.9 at Ishurdi and 99.0 at Jashore) was recorded in the plot receiving of 2 $\mathrm{kg} \mathrm{Zn} \mathrm{ha}{ }^{-1}$. The number of both branches and pods were recorded lowest in $\mathrm{Zn}$ control plot (Table 6). The highest seed weight (2.07 $\mathrm{g}$ at Gazipur, $2.31 \mathrm{~g}$ at Ishurdi and $2.23 \mathrm{~g}$ at Jashore) and maximum nodulation (34.5 at Gazipur, 35.2 at Ishurdi and 38.0 at Jashore) was obtained by the application of $2 \mathrm{~kg} \mathrm{Zn} \mathrm{ha}{ }^{-1}$ and both the parameters got lowest in $\mathrm{Zn}$ control plot (Table 7).

Table 6. Main effects of zinc on growth and yield attribute of lentil varieties.

\begin{tabular}{|c|c|c|c|c|c|c|c|c|c|}
\hline \multirow{2}{*}{$\begin{array}{l}\text { Zn level } \\
\left(\mathrm{kg} \mathrm{ha}^{-1}\right)\end{array}$} & \multicolumn{3}{|c|}{ Plant height (cm) } & \multicolumn{3}{|c|}{ No. of branches plant ${ }^{-1}$} & \multicolumn{3}{|c|}{ No. of pods plant ${ }^{-1}$} \\
\hline & Gazipur & Ishurdy & Jashore & Gazipur & Ishurdy & Jashore & Gazipur & Ishurdy & Jashore \\
\hline 0 & $28.1 \mathrm{~b}$ & $32.7 \mathrm{~b}$ & $33.5 b$ & $4.29 \mathrm{~b}$ & 4.92 & $5.46 \mathrm{~b}$ & $53.8 b$ & $74.9 \mathrm{~b}$ & $89.0 \mathrm{~b}$ \\
\hline 2 & $31.3 \mathrm{a}$ & $36.2 \mathrm{a}$ & $36.7 \mathrm{a}$ & $4.82 \mathrm{a}$ & 5.41 & $6.06 \mathrm{a}$ & $62.8 \mathrm{a}$ & $80.9 \mathrm{a}$ & $99.0 \mathrm{a}$ \\
\hline CV $(\%)$ & 6.52 & 7.42 & 6.70 & 11.7 & 15.7 & 11.3 & 5.41 & 4.66 & 7.0 \\
\hline $\operatorname{LSD}(0.05)$ & 1.81 & 1.99 & 1.81 & 0.29 & ns & 0.41 & 0.31 & 4.02 & 2.73 \\
\hline
\end{tabular}

In a column, the values having common letter do not differ significantly $(\mathrm{P} \leq 0.05)$

Table 7. Main effects of zinc on yield attribute of lentil varieties.

\begin{tabular}{|c|c|c|c|c|c|c|}
\hline \multirow{2}{*}{$\begin{array}{l}\text { Zn level } \\
\left(\mathrm{kg} \mathrm{ha}^{-1}\right)\end{array}$} & \multicolumn{3}{|c|}{100 seed wt. (g) } & \multicolumn{3}{|c|}{ No. of nodules plant ${ }^{-1}$} \\
\hline & Gazipur & Ishurdy & Jashore & Gazipur & Ishurdy & Jashore \\
\hline 0 & $1.96 \mathrm{~b}$ & $2.10 \mathrm{~b}$ & $2.19 \mathrm{~b}$ & $30.2 b$ & $28.9 \mathrm{~b}$ & $30.4 b$ \\
\hline 2 & $2.07 \mathrm{a}$ & $2.31 \mathrm{a}$ & $2.23 \mathrm{a}$ & $34.5 \mathrm{a}$ & $35.2 \mathrm{a}$ & $38.0 \mathrm{a}$ \\
\hline CV $(\%)$ & 4.79 & 9.81 & 0.77 & 14.3 & 14.8 & 16.2 \\
\hline $\operatorname{LSD}(0.05)$ & 0.02 & 0.05 & 0.01 & 0.88 & 0.97 & 0.96 \\
\hline
\end{tabular}

In a column, the values having common letter do not differ significantly $(\mathrm{P} \leq 0.05)$

The seed yield of lentil was exhibited significantly different between $\mathrm{Zn}_{0}$ and $2 \mathrm{~kg} \mathrm{Zn} \mathrm{ha}{ }^{-1}$ during all the years and all the locations (Table 8). The highest seed yield (1480 $\mathrm{kg} \mathrm{ha}^{-1}$ in $1^{\text {st }}$ year and $1193 \mathrm{~kg} \mathrm{ha}^{-1}$ in $2^{\text {nd }}$ year) at Gazipur was produced by the application of $2 \mathrm{~kg} \mathrm{Zn} \mathrm{ha}^{-1}$. In Ishurdy, the highest seed yield $\left(2166 \mathrm{~kg} \mathrm{ha}^{-1}\right.$ in $1^{\text {st }}$ year and $2333 \mathrm{~kg}$ $\mathrm{ha}^{-1}$ in $2^{\text {nd }}$ year) was achieved in the same $\mathrm{Zn}$ rate and it was produced highest $\left(1544 \mathrm{~kg} \mathrm{ha}^{-1}\right.$ in $1^{\text {st }}$ year and $1653 \mathrm{~kg} \mathrm{ha}^{-1}$ in $2^{\text {nd }}$ year) at Jashore in the plot receiving of $2 \mathrm{~kg} \mathrm{Zn} \mathrm{ha}^{-1}$. The lowest yield was found in all the years and locations in $\mathrm{Zn}$ control plot (Table 8). In the present study, harvest index (HI) of lentil was showed significant at Gazipur and it was nonsignificant at Ishurdy and Jashore between $\mathrm{Zn}_{0}$ and $2 \mathrm{~kg} \mathrm{Zn}$ $\mathrm{ha}^{-1}$ during all the years and all the locations (Table 8). The highest $\mathrm{HI}(42.9 \%)$ at Gazipur, (46.6\%) at Ishurdy and $(45.0 \%)$ at Jashore was documented by the application of 2 $\mathrm{kg} \mathrm{Zn} \mathrm{ha-1} \mathrm{and} \mathrm{it} \mathrm{was} \mathrm{lowest} \mathrm{at} \mathrm{Zn} \mathrm{control} \mathrm{plot} \mathrm{at} \mathrm{all} \mathrm{the}$ locations (Table 7). 
Table 8. Main effects of zinc on yield and harvest index of lentil varieties.

\begin{tabular}{|c|c|c|c|c|c|c|c|c|c|}
\hline \multirow{3}{*}{$\begin{array}{l}\text { Zn level } \\
\left(\mathrm{kg} \mathrm{ha}^{-1}\right)\end{array}$} & \multicolumn{6}{|c|}{ Seed yield $\left(\mathrm{kg} \mathrm{ha}^{-1}\right)$} & \multicolumn{3}{|l|}{ HI (\%) } \\
\hline & \multicolumn{2}{|c|}{ Gazipur } & \multicolumn{2}{|l|}{ Ishurdy } & \multicolumn{2}{|c|}{ Jashore } & \multirow{2}{*}{ Gazipur } & \multirow{2}{*}{ Ishurdy } & \multirow{2}{*}{ Jashore } \\
\hline & $\mathbf{1}^{\text {st }} \mathbf{Y r}$ & $2^{\text {nd }} Y r$. & $1^{\text {st }}$ Yr. & $2^{\text {nd }} Y r$. & $1^{\text {st }}$ Yr. & $2^{\text {nd }} Y r$. & & & \\
\hline 0 & $1184 b$ & $941 b$ & $1835 b$ & $2025 b$ & $1384 b$ & $1389 b$ & $41.8 \mathrm{~b}$ & 45.7 & 44.6 \\
\hline 2 & $1480 \mathrm{a}$ & $1193 a$ & $2166 a$ & $2333 a$ & $1544 \mathrm{a}$ & $1653 a$ & $42.9 \mathrm{a}$ & 46.6 & 45.0 \\
\hline CV (\%) & 14.5 & 14.2 & 10.4 & 9.66 & 9.86 & 11.5 & 1.87 & 5.85 & 3.41 \\
\hline $\operatorname{LSD}(0.05)$ & 153 & 38.7 & 189 & 163 & 89 & 64 & 0.66 & ns & ns \\
\hline
\end{tabular}

In a column, the values having common letter do not differ significantly $(\mathrm{P} \leq 0.05)$

In the trial, zinc exhibited significantly positive effect on protein and zinc content in lentil seed at all the locations of Gazipur, Ishurdy and Jashore (Table 9). The highest protein content $(27.6 \%)$ at Gazipur, $(28.1 \%)$ at Ishurdy and $(27.9 \%)$ at Jashore was estimated from the plot receiving of $2 \mathrm{~kg} \mathrm{Zn}$ $\mathrm{ha}^{-1}$ and it was lowest at $\mathrm{Zn}$ control plot at all the locations (Table 9). Similarly the highest zinc content (64.6 ppm) at Gazipur, (65.5 ppm) at Ishurdy and (62.4 ppm) at Jashore was determined from the same dose of zinc $\left(2 \mathrm{~kg} \mathrm{Zn} \mathrm{ha}^{-1}\right)$ (Table 9).

Table 9. Main effects of zinc on protein and zinc content in lentil varieties.

\begin{tabular}{|c|c|c|c|c|c|c|}
\hline \multirow{2}{*}{ Zn level (kg ha $\left.{ }^{-1}\right)$} & \multicolumn{3}{|c|}{ Protein content $(\%)$} & \multicolumn{3}{|c|}{ Zinc content (ppm) } \\
\hline & Gazipur & Ishurdy & Jashore & Gazipur & Ishurdy & Jashore \\
\hline 0 & $26.4 \mathrm{~b}$ & $26.6 b$ & $26.6 b$ & $57.7 \mathrm{~b}$ & $59.5 b$ & $58.7 \mathrm{~b}$ \\
\hline 2 & $27.6 \mathrm{a}$ & $28.1 \mathrm{a}$ & $27.9 \mathrm{a}$ & $64.6 \mathrm{a}$ & $65.5 \mathrm{a}$ & $62.4 \mathrm{a}$ \\
\hline CV $(\%)$ & 1.82 & 6.66 & 7.13 & 8.90 & 6.94 & 6.64 \\
\hline $\operatorname{LSD}(0.05)$ & 0.19 & 0.32 & 0.88 & 1.48 & 1.63 & 3.38 \\
\hline
\end{tabular}

In a column, the values having common letter do not differ significantly $(\mathrm{P} \leq 0.05)$

\subsection{Interaction Effect of Variety and Zinc}

The growth and yield attributes of lentil were positively influenced by the interaction of variety and zinc in all the locations (Tables $10 \& 11)$. In the study, the tallest plant of lentil $(34.9 \mathrm{~cm}$ at Gazipur, $38.7 \mathrm{~cm}$ at Ishurdy and $39.3 \mathrm{~cm}$ at Jashore) was recorded from the treatment combination of $\mathrm{V}_{6} \mathrm{Zn}_{2}$ which was showed significantly difference in most of the cases. The dwarf plant (26.0 $\mathrm{cm}$ at Gazipur, $29.9 \mathrm{~cm}$ at Ishurdy and $30.2 \mathrm{~cm}$ at Jashore) was found in $\mathrm{V}_{4} \mathrm{Zn}_{0}$ treatment (Table 10). In case of branches, the number of branches per plant was ranged across the combined variety and zinc treatments from 3.68 to 5.78 at Gazipur, 4.31 to 6.33 at Ishurdi and 5.00 to 6.88 at Jashore. The maximum number of branches per plant (5.78) was noted in $\mathrm{V}_{5} \mathrm{Zn}_{2}$ treatment which was statistically identical to $\mathrm{V}_{5} \mathrm{Zn}_{0}, \mathrm{~V}_{6} \mathrm{Zn}_{0}$ and $\mathrm{V}_{6} \mathrm{Zn}_{2}$ treatments at
Gazipur. The highest number of branches per plant (6.33 at Ishurdy and 6.88 at Jashore) was attained in the treatment $\mathrm{V}_{6} \mathrm{Zn}_{2}$ followed by $\mathrm{V}_{6} \mathrm{Zn}_{0}, \mathrm{~V}_{5} \mathrm{Zn}_{2}, \mathrm{~V}_{4} \mathrm{Zn}_{2}$ and $\mathrm{V}_{3} \mathrm{Zn}_{2}$ at both the locations and the lowest was in $\mathrm{V}_{1} \mathrm{Zn}_{0}$ treatment (Table 10). In Gazipur, BARI Masur-7 formed the highest number of pods per plant (70.3) in zinc treated plot which was significantly different over the other treatment of varieties and zinc treated or control. The lowest number of pods per plant (49.9) was recorded in $\mathrm{V}_{3} \mathrm{Zn}_{0}$ treatment. The maximum number of pods per plant (88.3 at Ishurdi and 110 at Jashore) was achieved by the variety BARI Masur-7 in $\mathrm{Zn}$ treated plot $\left(\mathrm{V}_{6} \mathrm{Zn}_{2}\right)$ which was statistically at par $\mathrm{V}_{2} \mathrm{Zn}_{2}$ in both Ishurdi and Jashore and at par $\mathrm{V}_{5} \mathrm{Zn}_{2}$ in Jashore. The lowest pods (72.0) was recorded at Ishurdi for $\mathrm{V}_{1} \mathrm{Zn}_{0}$ and (81.0) was found in $\mathrm{V} 3 \mathrm{Zn} 0$ treatment at Jashore (Table 10).

Table 10. Interaction effects of lentil variety and zinc on growth and yield attribute of lentil.

\begin{tabular}{|c|c|c|c|c|c|c|c|c|c|}
\hline \multirow{2}{*}{$\begin{array}{l}\text { Treatment } \\
\text { combination }\end{array}$} & \multicolumn{3}{|c|}{ Plant height (cm) } & \multicolumn{3}{|c|}{ No. of branches plant ${ }^{-1}$} & \multicolumn{3}{|c|}{ No. of pods plant ${ }^{-1}$} \\
\hline & Gazipur & Ishurdy & Jashore & Gazipur & Ishurdy & Jashore & Gazipur & Ishurdy & Jashore \\
\hline $\mathrm{V}_{1} \mathrm{Zn}_{0}$ & $27.8 \mathrm{~cd}$ & $33.3 \mathrm{bcd}$ & $34.3 \mathrm{bcd}$ & $3.84 \mathrm{ef}$ & $4.31 \mathrm{c}$ & $5.00 \mathrm{~b}$ & $50.2 \mathrm{e}$ & $72.0 \mathrm{c}$ & 87.0def \\
\hline $\mathrm{V}_{1} \mathrm{Zn}_{2}$ & $30.2 \mathrm{bc}$ & $35.5 \mathrm{abc}$ & $36.3 \mathrm{ab}$ & $4.00 \mathrm{def}$ & $4.77 b c$ & $5.12 b$ & $61.9 \mathrm{bc}$ & $77.0 \mathrm{bc}$ & $100 \mathrm{bc}$ \\
\hline $\mathrm{V}_{2} \mathrm{Zn}_{0}$ & $28.6 \mathrm{bcd}$ & $32.9 \mathrm{~cd}$ & $33.8 \mathrm{bcd}$ & $3.68 \mathrm{f}$ & $4.36 \mathrm{c}$ & $5.23 b$ & $55.3 d$ & $76.0 \mathrm{bc}$ & 88.0def \\
\hline $\mathrm{V}_{2} \mathrm{Zn}_{2}$ & $32.4 \mathrm{ab}$ & $36.9 \mathrm{abc}$ & $37.1 \mathrm{ab}$ & $4.15 c-f$ & $4.82 \mathrm{abc}$ & $5.55 \mathrm{~b}$ & $62.3 b c$ & $82.9 \mathrm{ab}$ & $103 \mathrm{ab}$ \\
\hline $\mathrm{V}_{3} \mathrm{Zn}_{0}$ & $26.9 \mathrm{~cd}$ & $30.3 d$ & $31.1 \mathrm{~cd}$ & 4.10def & $4.85 \mathrm{abc}$ & $5.43 b$ & $49.9 \mathrm{e}$ & $74.0 \mathrm{c}$ & $81.0 \mathrm{f}$ \\
\hline $\mathrm{V}_{3} \mathrm{Zn}_{2}$ & $28.7 \mathrm{bcd}$ & $34.6 a-d$ & $34.9 \mathrm{bc}$ & $4.56 \mathrm{~b}-\mathrm{e}$ & $5.24 \mathrm{abc}$ & $5.99 \mathrm{ab}$ & $55.6 \mathrm{~d}$ & $78.7 \mathrm{bc}$ & $84.0 \mathrm{ef}$ \\
\hline $\mathrm{V}_{4} \mathrm{Zn}_{2}$ & $28.9 \mathrm{bcd}$ & $33.8 \mathrm{bcd}$ & $34.4 \mathrm{bcd}$ & $4.74 b c d$ & $5.16 \mathrm{abc}$ & $6.00 \mathrm{ab}$ & $65.4 \mathrm{~b}$ & $78.9 \mathrm{bc}$ & $95.0 \mathrm{bcd}$ \\
\hline $\mathrm{V}_{5} \mathrm{Zn}_{0}$ & $28.8 \mathrm{bcd}$ & $34.5 \mathrm{a}-\mathrm{d}$ & $35.5 \mathrm{ab}$ & $5.10 \mathrm{ab}$ & $5.67 \mathrm{abc}$ & $5.77 \mathrm{~b}$ & $54.6 \mathrm{~d}$ & $74.4 \mathrm{c}$ & $96.0 \mathrm{bcd}$ \\
\hline $\mathrm{V}_{5} \mathrm{Zn}_{2}$ & $32.6 \mathrm{ab}$ & $37.7 \mathrm{ab}$ & $38.1 \mathrm{ab}$ & $5.78 \mathrm{a}$ & $6.19 \mathrm{ab}$ & $6.82 \mathrm{a}$ & $61.6 b c$ & $79.8 b c$ & $102 \mathrm{ab}$ \\
\hline $\mathrm{V}_{6} \mathrm{Zn}_{0}$ & $30.7 \mathrm{abc}$ & $35.7 \mathrm{abc}$ & $36.0 \mathrm{ab}$ & $5.00 \mathrm{abc}$ & $5.74 a b c$ & $6.00 \mathrm{ab}$ & $60.4 \mathrm{c}$ & $76.6 \mathrm{bc}$ & $92.0 \mathrm{cde}$ \\
\hline $\mathrm{V}_{6} \mathrm{Zn}_{2}$ & $34.9 \mathrm{a}$ & $38.7 \mathrm{a}$ & $39.3 \mathrm{a}$ & $5.68 \mathrm{a}$ & $6.33 \mathrm{a}$ & $6.88 \mathrm{a}$ & $70.3 \mathrm{a}$ & $88.3 \mathrm{a}$ & $110 \mathrm{a}$ \\
\hline CV (\%) & 8.39 & 7.94 & 7.12 & 8.83 & 16.8 & 9.85 & 0.72 & 7.10 & 4.01 \\
\hline $\operatorname{LSD}(0.05)$ & 4.43 & 4.87 & 4.44 & 0.72 & 1.55 & 1.01 & 0.75 & 9.84 & 6.71 \\
\hline
\end{tabular}

In a column, the values having common letter do not differ significantly $(\mathrm{P} \leq 0.05)$

Note: $\mathrm{V}_{1}=$ BARI Masur-2, $\mathrm{V}_{2}=$ BARI Masur-3, $\mathrm{V}_{3}=$ BARI Masur-4, $\mathrm{V}_{4}=$ BARI Masur-5, $\mathrm{V}_{5}=$ BARI Masur-6, and V $6=$ BARI Masur-7 
The heaviest seed (2.38 $\mathrm{g}$ at Gazipur and $2.44 \mathrm{~g}$ at Ishurdy) produced by the variety BARI Masur- 3 in zinc treated plot $\left(\mathrm{V}_{2} \mathrm{Zn}_{2}\right)$ which was non-significant. Significantly the highest test seed weight (2.43 g) was obtained in the treatment $\mathrm{V}_{6} \mathrm{Zn}_{2}$ at Jashore and the lowest was in $\mathrm{V}_{1} \mathrm{Zn}_{0}$ treatment (Table 11). In the experiment, the nodulation per plant of lentil varied across the combination of variety and zinc from 26 to 38.4 at Gazipur, 25 to 39.3 at Ishurdy and 26.4 to 43.4 at Jashore, however, the maximum number of nodules per plant was counted in the treatment $\mathrm{V}_{3} \mathrm{Zn}_{2}$ at Gazipur which was non-significant. It was recorded highest in the treatment $\mathrm{V}_{6} \mathrm{Zn}_{2}$ at Ishurdy and Jashore that was also showed non-significant (Table 11).

Table 11. Interaction effects of lentil variety and zinc on yield attribute of lentil.

\begin{tabular}{|c|c|c|c|c|c|c|}
\hline \multirow{2}{*}{$\begin{array}{l}\text { Treatment } \\
\text { combination }\end{array}$} & \multicolumn{3}{|c|}{100 seed wt. (g) } & \multicolumn{3}{|c|}{ No. of nodules plant ${ }^{-1}$} \\
\hline & Gazipur & Ishurdy & Jashore & Gazipur & Ishurdy & Jashore \\
\hline $\mathrm{V}_{1} \mathrm{Zn}_{0}$ & 1.73 & 2.05 & $1.83 \mathrm{i}$ & 26.7 & 25.0 & 26.4 \\
\hline $\mathrm{V}_{1} \mathrm{Zn}_{2}$ & 1.83 & 2.20 & $1.84 \mathrm{i}$ & 31.6 & 30.6 & 32.7 \\
\hline $\mathrm{V}_{2} \mathrm{Zn}_{0}$ & 2.20 & 2.13 & $2.25 \mathrm{ef}$ & 26.0 & 25.5 & 31.1 \\
\hline $\mathrm{V}_{2} \mathrm{Zn}_{2}$ & 2.38 & 2.44 & $2.28 \mathrm{de}$ & 29.2 & 30.0 & 38.9 \\
\hline $\mathrm{V}_{3} \mathrm{Zn}_{0}$ & 2.03 & 2.18 & $2.29 \mathrm{~cd}$ & 34.8 & 31.4 & 31.9 \\
\hline $\mathrm{V}_{3} \mathrm{Zn}_{2}$ & 2.08 & 2.36 & $2.32 \mathrm{c}$ & 38.4 & 37.9 & 38.6 \\
\hline $\mathrm{V}_{4} \mathrm{Zn}_{2}$ & 2.10 & 2.23 & $2.25 \mathrm{ef}$ & 34.2 & 37.8 & 37.6 \\
\hline $\mathrm{V}_{5} \mathrm{Zn}_{0}$ & 1.93 & 2.03 & $2.18 \mathrm{~h}$ & 31.8 & 28.0 & 29.3 \\
\hline $\mathrm{V}_{5} \mathrm{Zn}_{2}$ & 2.03 & 2.34 & $2.24 \mathrm{fg}$ & 35.7 & 35.6 & 37.0 \\
\hline $\mathrm{V}_{6} \mathrm{Zn}_{0}$ & 2.00 & 2.04 & $2.39 \mathrm{~b}$ & 31.3 & 32.6 & 32.6 \\
\hline $\mathrm{V}_{6} \mathrm{Zn}_{2}$ & 2.04 & 2.30 & $2.43 \mathrm{a}$ & 37.7 & 39.3 & 43.4 \\
\hline CV $(\%)$ & 1.34 & 3.13 & 0.79 & 3.74 & 4.17 & 3.9 \\
\hline $\operatorname{LSD}(0.05)$ & ns & $\mathrm{ns}$ & 0.03 & ns & ns & ns \\
\hline
\end{tabular}

In a column, the values having common letter do not differ significantly $(\mathrm{P} \leq 0.05)$

Note: $V_{1}=$ BARI Masur-2, $V_{2}=$ BARI Masur-3, $V_{3}=$ BARI Masur-4, $V_{4}=$ BARI Masur-5, V $5=$ BARI Masur-6, and V $6=$ BARI Masur-7

Seed yield of lentil influenced significantly by the interaction of variety and zinc at three locations like Gazipur, Ishurdy and Jashore during two years but was non-significant in $2^{\text {nd }}$ year at Jashore (Table 12). The highest seed yield (1664 $\mathrm{kg} \mathrm{ha}^{-1}$ in $1^{\text {st }}$ year and $1471 \mathrm{~kg} \mathrm{ha}^{-1}$ in $2^{\text {nd }}$ year) produced by the treatment $\mathrm{V}_{6} \mathrm{Zn}_{2}$ which was statistically identical to $\mathrm{V}_{5} \mathrm{Zn}_{2}$, $\mathrm{V}_{4} \mathrm{Zn}_{2}, \mathrm{~V}_{3} \mathrm{Zn}_{2}, \mathrm{~V}_{2} \mathrm{Zn}_{2}$ and $\mathrm{V}_{1} \mathrm{Zn}_{2}$ at Gazipur in $1^{\text {st }}$ year but it was significantly different over the other treatment combinations in $2^{\text {nd }}$ year. The lowest seed yield $\left(1079 \mathrm{~kg} \mathrm{ha}^{-1}\right.$ in $1^{\text {st }}$ year and $832 \mathrm{~kg} \mathrm{ha}^{-1}$ in $2^{\text {nd }}$ year) was recorded in the treatment combination of $\mathrm{V}_{1} \mathrm{Zn}_{0}$ at Gazipur (Table 12). The average seed yield of lentil varied from 956 to $1568 \mathrm{~kg} \mathrm{ha}^{-1}$ across the treatments where the highest yield $\left(1568 \mathrm{~kg} \mathrm{ha}^{-1}\right)$ was got from $\mathrm{V}_{6} \mathrm{Zn}_{2}$ treatment at Gazipur (Figure 1). In Ishurdy, the highest seed yield $\left(2268 \mathrm{~kg} \mathrm{ha}^{-1}\right.$ in $1^{\text {st }}$ year and $2523 \mathrm{~kg} \mathrm{ha}^{-1}$ in $2^{\text {nd }}$ year) was obtained from $\mathrm{V}_{6} \mathrm{Zn}_{2}$ treatment that statistically resembled in most of the treatment combinations. The lowest yield $\left(1799 \mathrm{~kg} \mathrm{ha}^{-1}\right.$ in $1^{\text {st }}$ year and $1633 \mathrm{~kg} \mathrm{ha}^{-1}$ in $2^{\text {nd }}$ year) was found in $\mathrm{V}_{1} \mathrm{Zn}_{0}$ treatment (Table 12). The average seed yield (mean of two years) of lentil ranged across the treatment combinations at Ishurdy from 1716 to $2396 \mathrm{~kg} \mathrm{ha}^{-1}$ but the greatest yield was found in $\mathrm{V}_{6} \mathrm{Zn}_{2}$ treatment (Figure 1). In Jashore, the highest seed yield (1669 $\mathrm{kg} \mathrm{ha}^{-1}$ in $1^{\text {st }}$ year and $1608 \mathrm{~kg} \mathrm{ha}^{-1}$ in $2^{\text {nd }}$ year) was achieved in $\mathrm{V}_{6} \mathrm{Zn}_{2}$ treatment that was significantly different with other treatments but showed statistically alike in most the treatments in $1^{\text {st }}$ year; however in $2^{\text {nd }}$ year it was showed non-significant. The lowest yield was found in $\mathrm{V}_{4} \mathrm{Zn}_{0}$ treatment in both the years (Table 12). The average seed yield (mean of two years) of lentil ranged among the different treatment combinations at Jashore from 1114 to $1639 \mathrm{~kg} \mathrm{ha}^{-1}$ but the highest yield was found in $\mathrm{V}_{6} \mathrm{Zn}_{2}$ treatment (Figure 1). Comparison among the three locations on mean seed yield across the treatment combination of variety and zinc indicated that the highest yield was observed at Ishurdy followed by Jashore and the lowest in Gazipur (Figure 1). In the experiment, the harvest index (HI) of lentil varied among the treatments from 40.9 to $45.0 \%$ at Gazipur while the highest harvest index (45.0\%) was calculated in the treatment $\mathrm{V}_{6} \mathrm{Zn}_{2}$ that was statistically similar to $\mathrm{V}_{6} \mathrm{Zn}_{0}$ and $\mathrm{V}_{5} \mathrm{Zn}_{2}$ treatment. The lowest $\mathrm{HI}$ was in $\mathrm{V}_{1} \mathrm{Zn}_{0}$ treatment (Table 12). In Ishurdy, the highest harvest index (46.9\%) was computed in $\mathrm{V}_{3} \mathrm{Zn}_{2}$ treatment which was showed non-significant. In Jashore, it was computed highest (45.8\%) in $\mathrm{V}_{5} \mathrm{Zn}_{2}$ treatment which was statistically at par most of the treatment combinations and the lowest HI (42.5\%) was in $\mathrm{V}_{4} \mathrm{Zn}_{0}$ treatment (Table 12).

Table 12. Interaction effects of lentil varieties and zinc on yield and harvest index (pooled data of two years) of lentil.

\begin{tabular}{|c|c|c|c|c|c|c|c|c|c|}
\hline \multirow{3}{*}{$\begin{array}{l}\text { Treatment } \\
\text { combination }\end{array}$} & \multicolumn{6}{|c|}{ Seed yield $\left(\mathrm{kg} \mathrm{ha}^{-1}\right)$} & \multicolumn{3}{|l|}{ HI (\%) } \\
\hline & \multicolumn{2}{|c|}{ Gazipur } & \multicolumn{2}{|l|}{ Ishurdy } & \multicolumn{2}{|l|}{ Jashore } & \multirow{2}{*}{ Gazipur } & \multirow{2}{*}{ Ishurdy } & \multirow{2}{*}{ Jashore } \\
\hline & $1^{\text {st }}$ Yr. & $2^{\text {nd }} \mathrm{Yr}$. & $1^{\text {st }}$ Yr. & $2^{\text {nd }} Y r$. & $1^{\text {st }}$ Yr. & $2^{\text {nd }} Y r$. & & & \\
\hline $\mathrm{V}_{1} \mathrm{Zn}_{0}$ & $1079 b$ & $832 \mathrm{f}$ & $1799 \mathrm{c}$ & $1633 c$ & $1526 \mathrm{ab}$ & 1137 & $40.9 \mathrm{~d}$ & 45.0 & $45.7 \mathrm{a}$ \\
\hline $\mathrm{V}_{1} \mathrm{Zn}_{2}$ & $1359 \mathrm{ab}$ & 1013 cde & $2060 \mathrm{abc}$ & $2100 \mathrm{~b}$ & $1559 \mathrm{ab}$ & 1645 & $41.4 \mathrm{~cd}$ & 45.4 & $45.5 \mathrm{a}$ \\
\hline $\mathrm{V}_{2} \mathrm{Zn}_{0}$ & $1146 b$ & $877 \mathrm{ef}$ & $1930 \mathrm{abc}$ & $2110 \mathrm{~b}$ & $1427 \mathrm{bc}$ & 1528 & $41.2 \mathrm{~cd}$ & 46.1 & $45.2 \mathrm{ab}$ \\
\hline $\mathrm{V}_{2} \mathrm{Zn}_{2}$ & $1378 \mathrm{ab}$ & $1120 \mathrm{bcd}$ & $2177 \mathrm{abc}$ & $2307 \mathrm{ab}$ & $1537 \mathrm{ab}$ & 1688 & $42.0 \mathrm{~cd}$ & 46.8 & $45.0 \mathrm{ab}$ \\
\hline $\mathrm{V}_{3} \mathrm{Zn}_{0}$ & $1202 b$ & 933def & $1830 \mathrm{bc}$ & $2100 \mathrm{~b}$ & $1210 \mathrm{~cd}$ & 1479 & $41.4 \mathrm{~cd}$ & 45.7 & $44.3 \mathrm{abc}$ \\
\hline
\end{tabular}




\begin{tabular}{|c|c|c|c|c|c|c|c|c|c|}
\hline \multirow{3}{*}{$\begin{array}{l}\text { Treatment } \\
\text { combination }\end{array}$} & \multicolumn{6}{|c|}{ Seed yield $\left(\mathrm{kg} \mathrm{ha}^{-1}\right)$} & \multicolumn{3}{|l|}{ HI (\%) } \\
\hline & \multicolumn{2}{|c|}{ Gazipur } & \multicolumn{2}{|l|}{ Ishurdy } & \multicolumn{2}{|l|}{ Jashore } & \multirow{2}{*}{ Gazipur } & \multirow{2}{*}{ Ishurdy } & \multirow{2}{*}{ Jashore } \\
\hline & $1^{\text {st }}$ Yr. & $2^{\text {nd }} \mathrm{Yr}$. & $1^{\text {st }} \mathrm{Yr}$. & $2^{\text {nd }} \mathrm{Yr}$. & $1^{\text {st }}$ Yr. & $2^{\text {nd }} Y r$. & & & \\
\hline $\mathrm{V}_{3} \mathrm{Zn}_{2}$ & $1443 \mathrm{ab}$ & $1191 b c$ & $2160 \mathrm{abc}$ & $2298 \mathrm{ab}$ & $1619 \mathrm{ab}$ & 1560 & $42.6 b c$ & 46.9 & $45.6 \mathrm{a}$ \\
\hline $\mathrm{V}_{4} \mathrm{Zn}_{0}$ & $1187 \mathrm{~b}$ & $903 \mathrm{ef}$ & $1860 \mathrm{abc}$ & $2187 \mathrm{ab}$ & $1118 \mathrm{~d}$ & 1110 & $41.7 \mathrm{~cd}$ & 46.5 & $42.5 \mathrm{c}$ \\
\hline $\mathrm{V}_{4} \mathrm{Zn}_{2}$ & $1384 a b$ & $1119 \mathrm{bcd}$ & $2100 \mathrm{abc}$ & $2356 a b$ & $1223 \mathrm{~cd}$ & 1423 & $42.6 \mathrm{bc}$ & 46.3 & $43.2 b c$ \\
\hline $\mathrm{V}_{5} \mathrm{Zn}_{0}$ & $1212 b$ & 966def & $1831 \mathrm{bc}$ & $2014 b c$ & $1497 \mathrm{ab}$ & 1520 & $41.9 \mathrm{~cd}$ & 45.2 & $45.1 \mathrm{ab}$ \\
\hline $\mathrm{V}_{5} \mathrm{Zn}_{2}$ & $1653 a$ & $1242 b$ & $2230 \mathrm{ab}$ & $2413 \mathrm{ab}$ & $1658 \mathrm{ab}$ & 1991 & $44.1 \mathrm{ab}$ & 46.6 & $45.8 \mathrm{a}$ \\
\hline $\mathrm{V}_{6} \mathrm{Zn}_{2}$ & $1664 \mathrm{a}$ & $1471 \mathrm{a}$ & $2268 \mathrm{a}$ & $2523 a$ & $1669 a$ & 1608 & $45.0 \mathrm{a}$ & 46.4 & $44.9 \mathrm{ab}$ \\
\hline CV (\%) & 15.8 & 5.0 & 13.1 & 10.3 & 8.35 & 5.74 & 2.15 & 5.47 & 1.77 \\
\hline LSD (0.05) & 375 & 94.8 & 464 & 401 & 217 & ns & 1.62 & ns & 1.41 \\
\hline
\end{tabular}

In a column, the values having common letter do not differ significantly $(\mathrm{P} \leq 0.05)$

Note: $\mathrm{V}_{1}=$ BARI Masur-2, $\mathrm{V}_{2}=$ BARI Masur-3, $\mathrm{V}_{3}=$ BARI Masur-4, $\mathrm{V}_{4}=$ BARI Masur-5, $\mathrm{V}_{5}=$ BARI Masur-6, and V6 $=$ BARI Masur-7

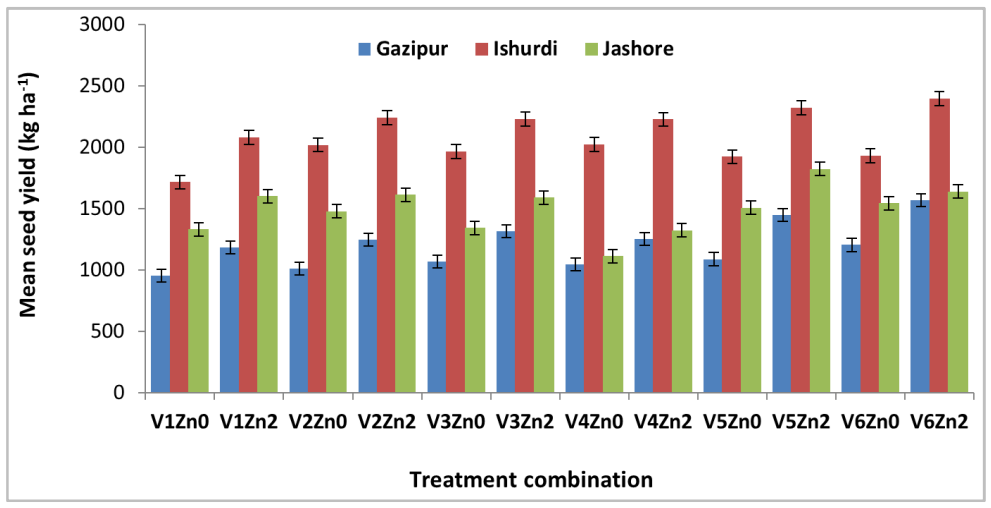

Figure 1. Seed yield variation among 3 locations due to different treatment combination.

Note: $\mathrm{V}_{1}=$ BARI Masur-2, $\mathrm{V}_{2}=$ BARI Masur-3, $\mathrm{V}_{3}=$ BARI Masur-4, $\mathrm{V}_{4}=$ BARI Masur-5, $\mathrm{V}_{5}=$ BARI Masur- 6 and $\mathrm{V}_{6}=$ BARI Masur-7

Error bar represent the SEM

Seed protein content of lentil affected positively by the interaction of variety and zinc at three locations like Gazipur, Ishurdy and Jashore but was showed non-significant at Ishurdy and Jashore (Table 13). The protein content ranged among the treatment combinations of variety and zinc from 25.9 to $28.5 \%$ at Gazipur, 26.2 to $28.9 \%$ at Ishurdy and 26.2 to $29.0 \%$ at Jashore, while the highest protein content was achieved in the treatment of $\mathrm{V}_{6} \mathrm{Zn}_{2}$ in all the locations and lowest content was found in $\mathrm{V}_{1} \mathrm{Zn}_{0}$ treatment at Gazipur and Jashore but it was lowest in $\mathrm{V}_{3} \mathrm{Zn}_{0}$ at Ishurdy (Table 13). In case of zinc content in seed, it was showed non-significant by the interaction of variety and zinc at Gazipur and Ishurdi. However, the zinc content of seed exhibited significant among the combination of different lentil varieties and $2 \mathrm{~kg}$ $\mathrm{Zn} \mathrm{ha}^{-1}$ at Jashore (Table 13). The highest zinc content (70.2 ppm at Gazipur and $73.6 \mathrm{ppm}$ at Ishurdy) was recorded from $\mathrm{V}_{6} \mathrm{Zn}_{2}$ treatment which was non-significant. In Jashore, the highest zinc content also recorded highest (69.9 ppm) in $\mathrm{V}_{6} \mathrm{Zn}_{2}$ treatment that was statistically identical with $\mathrm{V}_{6} \mathrm{Zn}_{0}$, $\mathrm{V}_{5} \mathrm{Zn}_{2}, \mathrm{~V}_{5} \mathrm{Zn}_{0}$ and $\mathrm{V}_{1} \mathrm{Zn}_{2}$ treatments (Table 13).

Table 13. Interaction effects of lentil variety and zinc on protein and zinc content in lentil seed.

\begin{tabular}{|c|c|c|c|c|c|c|}
\hline \multirow{2}{*}{$\begin{array}{l}\text { Treatment } \\
\text { combination }\end{array}$} & \multicolumn{3}{|c|}{ Protein content $(\%)$} & \multicolumn{3}{|c|}{ Zinc content (ppm) } \\
\hline & Gazipur & Ishurdy & Jashore & Gazipur & Ishurdy & Jashore \\
\hline $\mathrm{V}_{1} \mathrm{Zn}_{0}$ & $25.9 \mathrm{~d}$ & 26.3 & 26.2 & 54.9 & 55.6 & $56.8 \mathrm{~cd}$ \\
\hline $\mathrm{V}_{1} \mathrm{Zn}_{2}$ & $27.4 \mathrm{~b}$ & 27.8 & 27.6 & 62.3 & 64.3 & $63.2 \mathrm{abc}$ \\
\hline $\mathrm{V}_{2} \mathrm{Zn}_{0}$ & $26.3 d$ & 26.5 & 26.8 & 55.3 & 53.6 & $56.2 \mathrm{~cd}$ \\
\hline $\mathrm{V}_{2} \mathrm{Zn}_{2}$ & $27.4 b$ & 27.9 & 27.9 & 64.5 & 60.4 & $59.8 \mathrm{bcd}$ \\
\hline $\mathrm{V}_{3} \mathrm{Zn}_{0}$ & $26.2 d$ & 26.2 & 26.6 & 52.6 & 55.5 & $53.7 \mathrm{~d}$ \\
\hline $\mathrm{V}_{3} \mathrm{Zn}_{2}$ & $27.2 \mathrm{bc}$ & 27.7 & 28.3 & 56.8 & 59.5 & $54.7 \mathrm{~d}$ \\
\hline $\mathrm{V}_{4} \mathrm{Zn}_{2}$ & $27.8 \mathrm{ab}$ & 28.0 & 27.2 & 65.4 & 63.9 & $58.4 \mathrm{bcd}$ \\
\hline $\mathrm{V}_{5} \mathrm{Zn}_{0}$ & $26.1 d$ & 26.4 & 26.3 & 61.2 & 65.3 & $63.5 \mathrm{abc}$ \\
\hline $\mathrm{V}_{5} \mathrm{Zn}_{2}$ & $27.4 b$ & 28.1 & 27.8 & 68.4 & 71.4 & $68.2 \mathrm{a}$ \\
\hline $\mathrm{V}_{6} \mathrm{Zn}_{0}$ & $27.3 b$ & 27.7 & 27.4 & 64.5 & 68.5 & $65.8 \mathrm{ab}$ \\
\hline $\mathrm{V}_{6} \mathrm{Zn}_{2}$ & $28.5 \mathrm{a}$ & 28.9 & 29.0 & 70.2 & 73.6 & $69.9 \mathrm{a}$ \\
\hline CV (\%) & 0.99 & 1.60 & 4.43 & 3.33 & 3.58 & 7.71 \\
\hline $\operatorname{LSD}(0.05)$ & 0.48 & ns & ns & ns & ns & 8.29 \\
\hline
\end{tabular}

In a column, the values having common letter do not differ significantly $(\mathrm{P} \leq 0.05)$

Note: $\mathrm{V}_{1}=$ BARI Masur-2, $\mathrm{V}_{2}=$ BARI Masur-3, $\mathrm{V}_{3}=$ BARI Masur-4, $\mathrm{V}_{4}=$ BARI Masur-5, $\mathrm{V}_{5}=$ BARI Masur- 6 , and $\mathrm{V}_{6}=$ BARI Masur- 7 


\section{Discussion}

Pulses crops are generally grown in Bangladesh under rain-fed condition without proper nutrient management particularly zinc $(\mathrm{Zn})$ micronutrient [26]. For increasing the productivity of lentil appropriate variety need to be chosen and timely application of $\mathrm{Zn}$ micronutrient including other nutrients for plant growth and better performance of yield attributes, quality and high seed yield. Zinc application resulted to enhance the performance of growth, grain yield and quality [27]. Hafeez et al. [28] and Alloway [29] documented that zinc involved in many physiological functions of plant and its inadequate supply will be reduced crop yields. Experimental calcareous soil and other soil with high phosphorus are predictable to be $\mathrm{Zn}$ deficient which can be affected plant by growth stunting, decreasing number of pods, chlorosis and smaller leaves, sterility and inferior quality of harvested products. Hence, we compared the response of different lentil varieties to zinc fertilization in terrace and calcareous soils. Genetic variability responded to applied $\mathrm{Zn}$ has been noticed among different cultivars of pulses [27]. In the study, growth, yield attributes, quality and yield are influenced by different lentil varieties. Among the performance of varieties, BARI Masur-7 exhibited better followed by BARI Masur- 6 over the other lentil varieties. Uddin et al. [26] corroborated that BARI Masur-6 and BARI masur-7 can be grown and better performed in medium and high medium topography areas of Jessore, Chauadanga, Magura, meherpur, Kustia, Rajshahi, Gazipur districts of Bangladesh. In case of harvest index, two varieties BARI Masur-6 and BARI Masur-7 had reasonable plant height with better biomass production ability and improved harvest index and increased yield. Mondal et al. [30] reported that among the five promising lentil mutants, two mutants (LM-507 and LM-1018) showed improved HI, thereby increased yield.

Fertilization of grain legumes with $\mathrm{Zn}$ can affect both marketable yield and $\mathrm{Zn}$ content of the grain, which is important in human nutrition [31]. In the experiment, $\mathrm{Zn}$ fertilization significantly contributed to achieve higher yield and found improved growth, quality and yield contributing characters of lentil. Farooq et al. [32] reported that $\mathrm{Zn}$ played an important role in growth and development of crop yield. Seed yield of lentil increased in terrace and calcareous soils of all locations about 14 to $20 \%$ increment in $\mathrm{Zn}$ fertilization plot over $\mathrm{Zn}$ control plot. Grain yield can increase with $\mathrm{Zn}$ applications, which enhances plant growth due to the effects of $\mathrm{Zn}$ on photosynthesis and enzyme activation [33]. Quddus et al. [34] corroborated in field pea that application of different levels of $\mathrm{Zn}$ contributed $11.3 \%$ to $29.2 \%$ yield increment over $\mathrm{Zn}$ control. Zinc might be activated of several enzymes, involved in metabolic activities, assist nodule formation, protein synthesis resulting better pod formation which ultimately increase the seed yield. The results are in agreement with the findings of Mevada et al. [35]; Klug and Rhodes [36]. We observed that improved harvest index documented in $\mathrm{Zn}$ fertilization plot in all the experimental locations. This improved HI might be due to higher biomass accumulation. Harvest index showed statistically significant, some of them were showed non-significant across the treatments. Some researchers have outlined that the harvest index positively affected by $\mathrm{Zn}$ applications. Usman et al. [37] stated that the highest harvest index for green gram (Vigna radiata L.) obtained by the application of $20 \mathrm{~kg} \mathrm{ha}^{-1}$ zinc sulfate. Furthermore, Purushottam and Saren [38] emphasized that $\mathrm{Zn}$ fertilizer had a significant effect on the harvest index. Azad et al. [39] and Gangwar and Singh [40] found that applications of $\mathrm{Zn}$ increased the harvest index. But, some research report expressed that the application of $\mathrm{Zn}$ had no effect on the harvest index [41, 42].

In our study the effective nodulation was found highest in all the experimental locations in $\mathrm{Zn}$ fertilization plot of all varieties and lowest was in $\mathrm{Zn}$ control plot. The increasing rate of nodulation among the locations was about 14 to $25 \%$. Patel et al. [43] noted that $\mathrm{Zn}$ is involved in $\mathrm{N}$-fixation through nodule formation. The protein percentage in lentil affected significantly by the application of $\mathrm{Zn}$ including other $(\mathrm{N}, \mathrm{P}, \mathrm{K}, \mathrm{S}$ and $\mathrm{B})$ nutrients. In the experiment, the highest protein content was achieved in $\mathrm{Zn}$ fertilization plot in all the locations and lowest was in $\mathrm{Zn}$ control plot. Mali et al. [44] found that use of proper doses of zinc might be enhanced the synthesis of carbohydrates and protein and their transport to the site of seed formation. Oktem [45] reported that different levels of zinc fertilization increased protein content in seed of lentil varied from 24.9 to $29.8 \%$. Zinc is a vital micro element in protein synthesis [46, 47]. Pandey and Gautam [48] reported that the protein content of seeds significantly increased with the application of $\mathrm{Zn}$ in lentils. Application of $\mathrm{Zn}$ fertilizer generally increased the grain $\mathrm{Zn}$ concentration. Maqsood et al. [31] reported that low containing organic matter soils increase of $20 \%$ in $\mathrm{Zn}$ concentration in seed over control was observed when $5 \mathrm{~kg} \mathrm{Zn} \mathrm{ha}^{-1}$ was added to a loamy textured soil. In the experiment, the $\mathrm{Zn}$ concentration augmented 6.3 to $12 \%$ among the locations over $\mathrm{Zn}$ control treatment. Some researchers have reported that the application of $\mathrm{Zn}$ to the soil had a significant positive effect on seed $\mathrm{Zn}$ content $[49,50]$. Comparison among three locations, the productivity and performance of lentil varieties found comparatively better in calcareous soil than that of terrace soil. These improved variation might be due to soil fertility of calcareous soils was better over terrace soils.

The above results and explanations advocated advance to the appropriate requirement of zinc dose for the targeted soil fertility in order to monitor the different $\mathrm{Zn}$ rates to achieve maximum lentil production.

\section{Conclusion}

Experimental results indicated that $\mathrm{Zn}$ fertilization increased the seed yield taken per unit area. Among the varieties, BARI Masur-7 followed by BARI Masur-6 produced the highest seed yield in most of the cases by the application of $2 \mathrm{~kg} \mathrm{Zn} \mathrm{ha}^{-1}$. Growth and yield contributing 
characters responded positively to $\mathrm{Zn}$ application in the zinc deficient soils. Protein and $\mathrm{Zn}$ content in lentil seed also improved by the application of $\mathrm{Zn}$ fertilizer. The result, suggest that $2 \mathrm{~kg} \mathrm{Zn} \mathrm{ha}{ }^{-1}$ could be applied in any lentil variety for quality improvement and yield maximization in terrace and calcareous soils of Bangladesh. Recommendation has been made from the current study, another experiment should be carried out to monitor and determine the appropriate $\mathrm{Zn}$ dose and dynamic for lentil production through different zinc levels in $\mathrm{Zn}$ - deficient soils.

\section{References}

[1] Das, S. and Kabir W. (2016). Pulses production in Bangladesh: status and drivers for enhancement. Published by Bangladesh Agricultural Research Council (BARC), Dhaka, Bangladesh.

[2] Erskine, W. and Sarker A. (2004). Lentil. In: Corke H, Walker CE (ed) Encyclopedia of grain sciences. Elsevier, London, UK, 2004, 142-150.

[3] Agriculture and Agri-Food Canada (AAFC). 2010. Market outlook report. Lentils: Situation and outlook. Available at www.agr.gc.ca/gaod-dco (verified 4 Oct. 2014).

[4] Ali, A., Ahmad B., Hussain I., Ali A. and Ali Shah F. (2017). Effect of phosphorus and zinc on yield of lentil. Pure and Applied Biology, 6 (4): 1397-1402.

[5] Jahiruddin, M. (2015). Zinc and boron deficiency in crops and their management in Bangladesh. Department of Soil Science, Bangladesh Agricultural University, Mymensingh, pp 1-27.

[6] Hossain, M. A. (2007). Requirement of boron for MustardMungbean-Rice pattern and zinc for Maize-Mungbean-Rice pattern in calcareous soil. PhD Thesis, Department of Soil Science, BAU, Mymensingh. Pp 1-2.

[7] Rashid, M. M. (2001). Agroecological characteristics of Bangladesh. In: M. A. Wadud Mian, F. M. Maniruzzaman, M. A. Sattar, M. A. Aziz Miah, S. K. Paul and K. R. Haque (eds.) Agricultural Research in Bangladesh in the 20th Century. Bangladesh Agricultural Research Council \& Bangladesh Academy of Agriculture, Dhaka. Pp. 37-42.

[8] FRG. (2012). Fertilizer Recommendation Guide. Published by Bangladesh Agricultural Research Council, Dhaka, Bangladesh.

[9] BBS, (2016). Yearbook of Agricultural Statistics of Bangladesh-2015. Bangladesh Bureau of statistics. Statistics and informatics Division. Ministry of planning. Government of the people's republic of Bangladesh. Dhaka. p. 138.

[10] Fageria, N. K., Baligar V. C. and Clark R. B. (2002). Micronutrients in Crop Production. Advances in Agronomy, 77: $185-268$.

[11] Loneragan, J. F. and Webb, M. J. (1993). Interactions between zinc and other nutrients affecting the growth of plants. In: Zinc in soils and plants (Robson A. D., ed). Kluwer Academic Publishers, Dordrecht, The Netherlands. pp. 45-57.

[12] Khan, H. R., McDonald, G. K., and Rengel, Z. (2004). Zinc fertilization and water stress affects plant water relations, stomatal conductance and osmotic adjustment in chickpea
(Cicer arietinum). Plant Soil, 267: 271-284.

[13] Valenciano, J. B., Bato J. A., and Marcelo, V. (2010). Response of chickpea (Cicer arientinum L.) yield to Zinc, boron and molybdenum application under pot conditions. Spanish Journal of Agricultural Research, 8, 797-807.

[14] Sommer, Anna L., and Lipman, C. B. (1926). Evidence on the indispensable nature of zinc and boron for higher green plants. Plant Physiology, 1: 231-249.

[15] Obata, H., Kawamura, Senoo K. and Tanaka A. (1999). Changes in the level of protein and activity of $\mathrm{Cu} / \mathrm{Zn}$ superoxide dismutase in zinc deficient rice plant, Oryza sativa L. Soil Sci. Plant Nutr. 45: 891-896.

[16] Page, A. L., Miller R. H. and Keeney D. R. (Eds.). (1982). Agronomy Series 9 ASA, SSSA. Methods of Soil Analysis (Part 2, 2nd ed., pp. 403-427). American Society of Agronomy, Madison, USA.

[17] Bremner, J. M. and Mulvaney, C. S. (1982). Total nitrogen. In A. L. Page, R. H. Miller, D. R. Keeney (Eds.), Methods of Soil Analysis (Part 2, 2nd ed., pp. 599-622). American Society of Agronomy, Madison, USA.

[18] Bray R. H. and Kurtz L. T. (1945). Determination of total, organic and available forms of phosphorus in soils. Ibid. 59: $39-45$.

[19] Jackson, M. L. (1973). Soil Chemical Analysis (p. 498). Prentice Hall of India Private Limited, New Delhi.

[20] Gupta, P. K. (2004). Soil, Plant, Water and Fertilizer Analysis. Department of Agricultural Chemistry and Soil Science, Maharana Pratap University of Agriculture \& Technology, Rajasthan, India, Pp 168-170.

[21] Fox, R. L.; Olsen, R. A.; Rhoades, H. F. (1964). Evaluating the sulphur status of soil by plant and soil test. Soil Science Society of America Proc., 28, 243-246.

[22] Lindsay, W. L. and Norvell, W. A. (1978). Development of DTPA soil test for zinc, iron, manganese and copper. Soil science Society of American Journal, 42: 421-8.

[23] Piper, C. S. (1964). Soil and Plant Analysis. Adelaide University Press, Australia.

[24] Hiller, A., J. Plazin and D. D. Vanslyke. (1948). A study of conditions of Kjeldhal determination of nitrogen in proteins. Journal of Biological Chemistry, 176 (3): 1401-1420.

[25] Statistix 10. (1985). An Analytical Software, Po Box 12185, Tallahassee, FL 32317, Copy right (C) 1985-2013.

[26] Uddin, J., Sarker A., Podder R., Afzal A., Rashid H. and Siddique K. H. M. (2014). Development of new lentil varieties in Bangladesh. http:www.regional.org.au/au/asa/2008/posterfocussed-research/5654

[27] Singh, K. K., Praharaj, C. S., Choudhary A. K., Narendra Kumar and Venkatesh M. S. (2015). Zinc Response in Pulses. Indian Journal of Fertilizers, 7 (10): 118-126.

[28] Hafeez, B., Khanif Y. M. and Saleem M. (2013). Role of zinc in plant nutrition- A Review. American Journal of Experimental Agriculture, 3 (2): 374-391.

[29] Alloway, B. J. (2008). Zinc in Soils and Crop Nutrition. Second edition, published by IZA and IFA Brussels, Belgium and Paris, France, 2008. 
[30] Mondal, M. M. M., Puteh A. B., Malek M. A., Roy S. and Yusop M. R. (2013). Contribution of morpho-physiological traits on yield of lentil (Lens culinaris Medik). Australian Journal of Crop Science, 7980: 1167-1172.

[31] Maqsood, A. M., Schoenau J. \& Vandenberg A. (2016). Zinc fertilization of lentil for grain yield and grain zinc concentration in ten Saskatchewan soils, Journal of Plant Nutrition, 39: 6, 866-874.

[32] Farooq M, Wahid A \& Siddique KHM (2012). Micronutrient application through seed treatments: a review. Journal of Soil Science and Plant Nutrition, 12: 125-142.

[33] Hussain, I., and Ahmad B. (2015). Effect of Nitrogen and Zinc Application on Growth, Yield and Seed Recovery of Wheat Crop. Peshawar, Pakistan: KPK Agricultural University.

[34] Quddus, M. A., Hossain M. A., Naser H. M., Anwar B., Aktar S. and Nazimuddin M. (2018). Effect of zinc and boron application on productivity, quality and nutrient uptake of fieldpea (Pisum sativum L.) grown in calcareous soils. Journal of Agricultural Science and Practice, 3 (6): 132-143.

[35] Mevada, K. D., Patel, J. J., \& Patel, K. P. (2005). Effect of micronutrients on yield of urdbean. Indian Journal of Pulses Research, 18, 214-6.

[36] Klug, A. and Rhodes, D. (1987). "Zinc fingers": A Noval protein motif for nucleic acid recognition. Trends in Biochemical Sciences, 12: 464-469.

[37] Usman M., Tahir M. and Majeed M. A. (2014). Effect of zinc sulphate as soil application and seed treatment on green gram (Vigna radiata L.). Pakistan Journal of Life and Social Sciences, 12: 87-91.

[38] Purushottam AG and Saren BK (2018). Effect of irrigation scheduling and zinc application on yield attributes and yield of chickpea (Cicer arietinum L.). Bioscience Trends 11: 376-378.

[39] Azad AS, Manchada JS, Gill AS, Bains SS (1993). Effect of zinc application on grain yield, yield components and nutrient content of lentil. Lens Newsletter 20: 30-33.

[40] Gangwar KS, Singh NP (1986). Effect of zinc application on yield and quality of lentil (Lens cullinaris Medic.) Legume Research, 1: 11-14.
[41] Singh RP, Shukla VK, Yadav RS, Sharma PK, Singh PK, Pandey AC (2011). Biological approach of zinc oxide nanoparticles formation and its characterization. Advanced Materials Letters 2: 313-317.

[42] Singh, A. K. and Bhatt B. P. (2015). Late-sown lentil performance in response to foliar application of zinc. Bangladesh Journal of Botany, 44: 125-128.

[43] Patel, M. M., Patel, I. C., Patel, R. I., \& Acharya, S. (2011). Effect of Zinc and Iron on yield and yield attributes of rainfed cowpea (Vigna unguiculata L. Walp). Annals of Arid Zone, 50 (1), 17-19.

[44] Mali, G. C., Sharma, N. N., Acharya, H. K., Gupta, S. K., \& Gupta, P. K. (2003). Response of pigeon pea to $\mathrm{S}$ and $\mathrm{Zn}$ fertilization on vertisols in south-eastern plain of Rajasthan. Advances in Arid Legumes Research, pp. 267-271. Indian Arid Legumes Society, Scientific Publishers (India), Jodhpur.

[45] Oktem, A. G. (2019). Effects of different zinc levels on grain yield and some phenological characteristics of red lentil (Lens culinaris Medic.) under arid conditions. Turkish Journal of Agriculture and Forestry, 43: 360-367.

[46] Esfandiari, E. and Abdoli M. (2016). Wheat biofortification through zinc foliar application and its effects on wheat quantitative and qualitative yields under zinc deficient stress. Yüzüncü Yıl Üniversitesi Tarım Bilimleri Dergisi, 26: 529-537.

[47] Martinez, M. F., Vicca S., Janssens I. A., Espelta J. M., Penuelas J. (2017). The role of nutrients, productivity and climate in determining tree fruit production in European forests. New Phytol 213: 669-679.

[48] Pandey, S. N. and Gautam S. A. (2009). Effects of zinc supply on its uptake, growth and biochemical constituents in lentil. Indian Journal of Plant Physiology, 14: 67-70.

[49] Kaya, M., Zeliha K. and Albrahin E. (2009). Phytase activity, phytic acid, zinc, phosphorus and protein contents in different chickpea genotypes in relation to nitrogen and zinc fertilization. African Journal of Biotechnology, 8: 4508-4513.

[50] Shivay, Y. S., Prasad R. and Pal M. (2014). Effect of variety and zinc application on yield, profitability, protein content and zinc and nitrogen uptake by chickpea (Cicer arietinum). Indian Journal of Agronomy, 59: 317-321. 